aqueous ethanol. In the enzymic hydrolysis, $10 \mathrm{mgm}$. quercetin glucosiduronic acid yielded $4 \cdot 2 \mathrm{mgm}$. quercetin after $24 \mathrm{hr}$. incubation at $38^{\circ}$, correspond. ing to 75 per cent hydrolysis. There was no depression of the melting points on admixture with an authentic specimen of quercetin, melting point $305-306^{\circ}$ (uncorr.). The product of hydrolysis and authentic quercetin when treated with anhydrous sodium acetate and acetic anhydride yielded identical penta-acetates, melting points $191-192^{\circ}$ and $193-194^{\circ}$ (corr.) respectively. Examination of the ultra-violet spectral adsorption in ethanolic solution showed adsorption maxima at 260 and $361 \mathrm{~m} \mu$ for quercetin glucosiduronic acid, and at 256 and $373 \mathrm{~m} \mu$ for quercetin.

Determination of reducing sugar showed that the enzymic hydrolysis was strongly inhibited by a boiled glucosaccharate solution (a $2.5 \times 10^{-4} M$ solution caused 70 per cent inhibition of the hydrolysis of a $2.5 \times 10^{-3} M$ quercetin glucosiduronic acid solution), proving that the responsible enzyme was $\beta$-glucuronidase and thus that the glycoside has a $\beta-D$ glucopyranoside strueture ${ }^{2}$. The value of $K_{m}$, the dissociation constant of the enzyme-substrate complex, for quercetin glucosiduronic acid was determined indirectly by its action as a competing substrate in the hydrolysis of phenolphthalein glucuronide by mouse-liver $\beta$-glucuronidase. Mean values for $K_{m}$ of $6.9 \times 10^{-6} M$ at $p \mathrm{H} 4.5$, and $9.8 \times 10^{-6} M$ at $p \mathrm{H} 5.2$ were obtained-that is, similar to the values found for other plant flavone glucosiduronic acids ${ }^{2}$.

When tested by the procedure of Levvy ${ }^{2}$, there was no evidence of the existence in the leaf, root or root nodules of the French bean of an enzyme capable of decomposing phenolphthalein glucuronide at $p \mathbf{H} 4 \cdot 5$.

Table 1

\begin{tabular}{|c|c|c|}
\hline Aglycone & $\begin{array}{l}\text { Positions of nuclear } \\
\text { hydroxyls in fiavone }\end{array}$ & Source of glucosiduronic acid \\
\hline $\begin{array}{l}\text { Chrysin } \\
\text { Apigenin* } \\
\text { Baicalein } \\
\text { Scutellarein } \\
\text { Quercetin }\end{array}$ & $\begin{array}{c}5,7 \\
5,7,4^{\prime} \\
5,6,7 \\
5,6,7,4^{\prime} \\
3,5,7,3^{\prime}, 4^{\prime}\end{array}$ & $\begin{array}{l}\text { Leaf of Scutellaria galericulata } \\
\text { Flower of Erigeron annuus } \\
\text { Root of Scutellaria baicalensis } \\
\text { Leaf of Scutellaria sp. Leaf } \\
\text { of Centaurea scabiosa } \\
\text { Leaf of Phaseolus vulgaris }\end{array}$ \\
\hline
\end{tabular}

- In this instance, the $\beta$-glucopyranuronide structure of the glucosiduronic acid has still to be demonstrated.

It is interesting to note that a few plants are able to synthesize betero-glucosiduronic acids akin to those excreted by animals. The structural similarity of the parent flavones is demonstrated in Table 1 . In the case of apigenin glucosiduronic acid, the point of conjugation with glucuronic acid has been shown to be at $\mathrm{C}_{7}$ of the flavone nucleus ${ }^{3}$; it had previously been suggested ${ }^{5}$, from indirect evidence, that this was also the position of glycosidic linkage for baicalein and scutellarein.

I thank the North of Scotland College of Agriculture for cultivating the beans used in these experiments.

Rowett Research Institute, C. A. MaRSH

Bucksburn

Aberdeenshire. March 8.

1 Marsh, C. A., Biochem. J., 59, 58 (1955).

Levvy, G. A., Biochem. J., 58, 462 (1954).

Imai, K., and Mayama, T., J. Pharm. Soc., Japan, 73, 131 (1953); Chem. Abs., 47, 12370 (1953).

- Endres, G., Huttel, R., and Kaufmann, L., Annalen, 587, 205 (1939).

- Shibata, K., and Hattori, S., Acta phytochim., Tokyo, 5, 117 (1930).

\section{"Adult Education"}

THe main thesis of the article on "Adult Education" which appeared in Nature of May 7 (p. 783) seems to be that the present weakness of the Workers' Educational Association is largely attributable to the activitios of "a fow universiny extra-mural departments [which] found that it was simpler to arrange classes by dispensing altogether with the services of W.E.A. branches". This is not in accordance with the facts. Every extra-mural department, except one, provides classes and courses in co-operation with W.E.A. branches, and the exception (Aberys:wyth) has never done so. Some make rather less provision than they did a few years ago; but the reasons for this are not as simple as the article in Nature suggests. It is certainly not the case that this change has come about through the deliberate action of any extra-mural department. Although no department would now concede to the W.E.A. the exclusive right of interpreting its university to the people as a whole, departments still look to the W.E.A. to do this among working-people.

There is probably a causal connexion between the recent modest decline in university extra-mural provision through the W.E.A. and the appreciable increase in university extension; but it is very indirect. The rebirth of the latter, which is one of the outstanding features of post-war development in adult education, is due chiefly to the discovery that, for extra-mural work of a certain kind, there is a public which the W.E.A. is unable to reach. This consists of people who have had a good secondary or even a tertiary education, to whom the "education for social purpose" of the W.E.A. makes no appeal. Some members of this public wish for provision which will widen or refresh their professional education; others, whose full-time education was very highly specialized, wish to study (at a level suited to their abilities) subjects which they had to leave aside in their college or university days. It is surely not improper for extra-mural departments to try to satisfy the needs of this public. Yet it would seem to be so according to the article in Nature.

University extension designed for its new public is said to be provided directly by extra-mural departments- "laid on" is the term used in the article. If this statement is intended to imply that extramural departments normally prepare their extension programmes in the light of coolly calculated market prospects, and then proceed, by high-pressure salesmanship, to sell to the public what they have devised, it is very wide of the mark. Before any programme is drawn up, many interests are consulted-professional, scientific, religious, etc.-and in promoting classes and courses there is the closest co-operation with a great variety of bodies representing prospective students. It is wrong to suggest that provision, other than that through the W.E.A., is devoid of the voluntary principle. The recent growth of extension provision in science, to which Dr. H. D. Turner's article in Nature on "Science and Adult Education" (January 22, p. 142) refers, has been due almost entirely to close collaboration between the officers of extra-mural departments and voluntary bodies especially interested in science.

$$
\text { A. J. Allaway }
$$

Department of Adult Education, University College, Leicester. June 21. 